\title{
Phylogenetic relationships of the triclads (Platyhelminthes, Seriata, Tricladida)
}

\author{
Ronald Sluys \\ Institute of Taxonomic Zoology, University of Amsterdam, P.O. Box 4766, 1009 AT Amsterdam, \\ The Netherlands
}

Keywords: Plathyhelminthes, Tricladida, phylogeny

\begin{abstract}
1. A phylogenetic hypothesis for the triclads is presented and the characters on which it is based are discussed.

2. The sister group of the Tricladida is formed by the Bothrioplanida, and together the two taxa share a sistergroup relationship with the Proseriata.

3. The monophyletic status of the suborder Tricladida is supported by several derived features (Fig. 1., characters 9-12), including a unique embryological development and the presence of a marginal adhesive zone.

4. It is postulated that the Maricola is the primitive sister group of the Terricola and the Paludicola together and that the Paludicola represents the most advanced group within the Tricladida. Characters supporting these hypotheses are discussed (Fig. 1, characters 14-16, and 20-22, respectively).

5. Within the Paludicola the Planariidae and the Dendrocoelidae together are the sister group of the Dugesiidae (Fig. 1, character 24).

6. The monophyletic status of the Maricola and the Terricola is supported by one and three apomorphic characters, respectively (Fig. 1, characters 13, and 17-19).

7. Cases of conflicting or not sufficiently resolved character distributions are discussed and are evaluated in order to arrive at a phylogenetic tree providing the best fit to the data set considered.
\end{abstract}

\section{Résumé}

1. On présente une hypothèse phylogénétique pour les triclades, et on discute les caractères sur lequels celle-ci est fondée.

2. Le groupe-frère de Tricladida et celui des Bothrioplanida; ces deux taxa ensemble ont comme groupe-frère les Proseriata.

3. Plusieurs caractères dérivés (Fig. 1, caractères 9-12) viennent à l'appui du statut monophylétique du sous-ordre Tricladi- da; parmi ceux-ci, un développement embryonnaire unique et la présence d'une zone marginale adhésive.

4. On considère les Maricola comme group-frère plus primitif de la paire de taxa Terricola + Paludicola, et les Paludicola comme représentant le groupe le plus dérivé des Tricladida. Sont discutés les caractères venant à l'appui de ces hypothèses (Fig. 1, caractères 14-16 et respectivement 20-22).

5. Au sein des Paludicola, les Planariidae et les Dendrocoeliidae représentent ensemble le groupe-frère des Dugesiidae (Fig. 1 , caractère 24).

6. A l'appui du statut monophylétique des Maricola et des Terricola on mentionne un caractère, et respectivement trois caractères apomorphes (Fig. 1, caractère 13, et respectivement 17-19).

7. Sont discutés les cas contradictoires ou insuffisamment clairs de distributions de caractères; ceci permet d'aboutir à l'arbre phylogénétique le mieux en accord avec les données prises en considération.

\section{Introduction}

At present, phylogenetic research on the flatworms (Platyhelminthes) is in a state of flux. This is witnessed by studies dealing with the relationships among the orders within the Platyhelminthes (cf. Ehlers, 1985) and by studies which tackle subgroups of the phylum, such as, for example, Ball (1974a) on the Dugesiidae, Tajika (1982a) on the Coelogynoporidae, and Brooks et al. (1985a, b) on the parasitic flatworms.

The present paper deals with the phylogenetic relationships of the triclads or planarians, representing a group of flatworms which has been subjected to a wide range of studies, involving mor- 


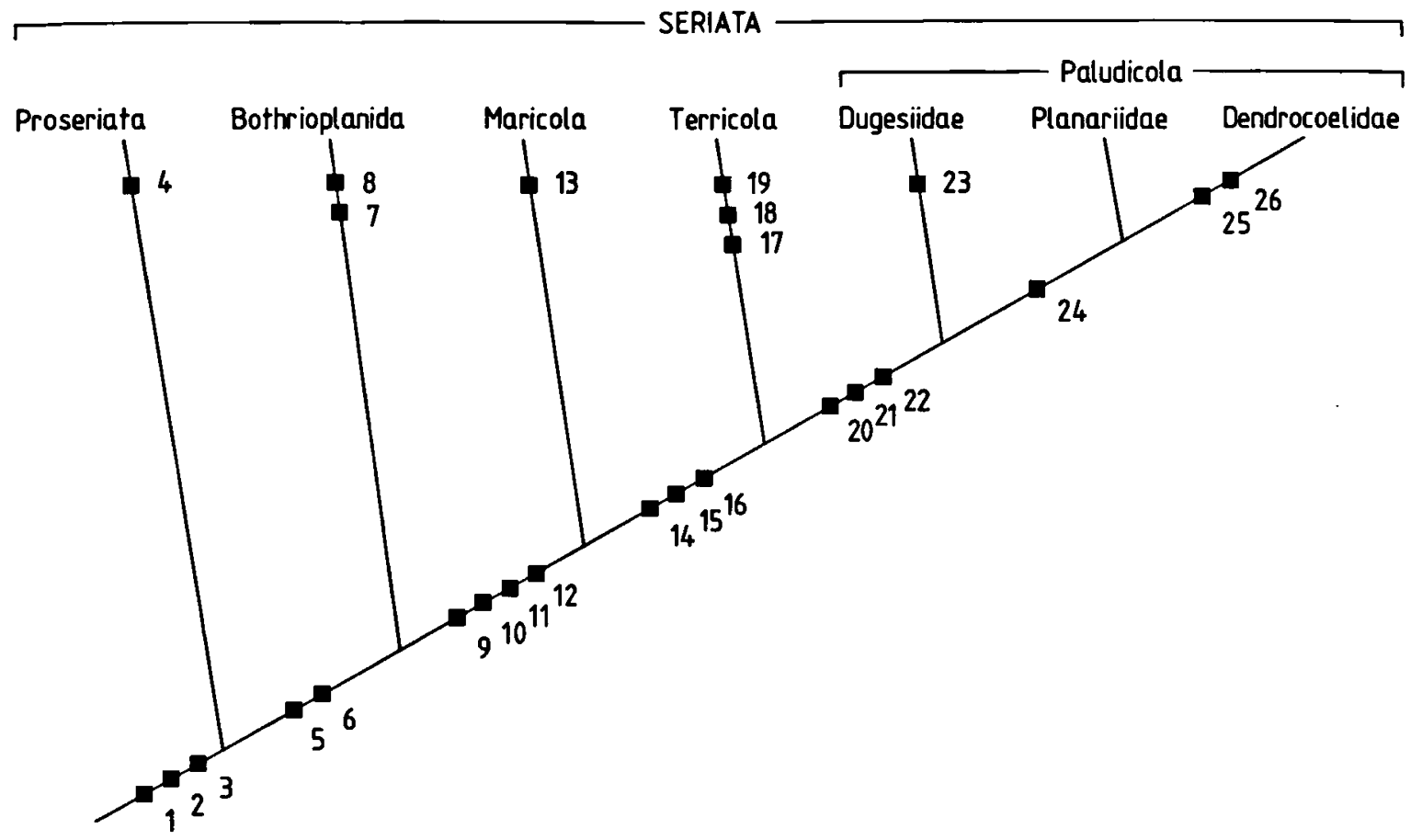

Fig. 1. Phylogenetic hypothesis for the Tricladida. Numbers refer to postulated derived characters: 1 , serial arrangement of testes and vitellaria; 2, backwards directed tubiform and plicate pharynx; 3, elongate body shape; 4 , loss of lamellated rhabdites; 5 , tricladoid intestine; 6 , crossing-over of pharynx muscles; 7 , parthenogenetic reproduction; 8 , four pairs of longitudinal nerve cords; 9 , embryology; 10, cerebral position female gonads; 11 , serial arrangement of many nephridiopores; 12, marginal adhesive zone; 13, Haftpapillen in annular zone; 14, loss of Haftpapillen; 15, resorptive vesicles; 16, reduction number of longitudinal nerve cords; 17 , creeping sole; 18, pharynx musculature; 19 , diploneuran nervous system; 20 , four subepidermal muscle layers; 21 , spermatophore; 22 , probursal condition; 23, dugesiid eye; 24 , common oviduct opening into atrium; 25 , dendrocoelid pharyngeal musculature; 26 , anterior adhesive organ (for further explanation, see text).

phology, physiology, karyology, ecology and regeneration. The Tricladida, which is best considered a suborder according to Ehlers' (1985) scheme, subsumes three subgroups or infraorders, viz. the Paludicola, Terricola, and Maricola. To the Paludicola belong the well-known freshwater triclads, whereas the Terricola and Maricola represent the land- and marine planarians, respectively. Although in the majority of cases there is no problem in recognizing whether a particular triclad belongs to the Paludicola, Terricola, or Maricola, these infraorders always have been poorly defined from a phylogenetic point of view. Further research on the planarians has been hampered by the fact that the phylogenetic relationships between the three infraorders were virtually unknown, or at least highly problematical, as has been pointed out by Ball (1981). For example, Ball (1974a) ex- perienced difficulties in analyzing the phylogeny and historical biogeography of the freshwater planarians of the family Dugesiidae because of the lack of a well-substantiated hypothesis on the affinities between the Maricola, Terricola, and Paludicola.

In this paper I review the phylogenetic status of the Tricladida and put forward an hypothesis on the phylogenetic relationships between the three infraorders. The aim of this study is to present a phylogenetic tree based on the strongest possible evidence available at present and to discuss the characters involved. This will enable, and hopefully stimulate, workers in this field to test a specific hypothesis against future investigations. In a study such as this one, hypothesized apomorphic or plesiomorphic characters are always based on only a sample of all the taxa involved, and it is only 
through a joint effort that we may be able to check whether the derived or primitive status of features applies to all species and species groups for which they are supposed to hold true.

\section{Material and methods}

The characters used were selected by a combination of literature search and specimen examination. There are only a few publications which give information on possible suites of characters relevant to various aspects of the phylogenetic relationships of the Tricladida, viz. Steinböck (1925), Meixner (1928), Kenk (1930), Karling (1974), Ball (1981), and Sopott-Ehlers (1985). Other information was obtained from primary literature sources.

I have been able to examine the majority of the species of marine triclads but from the other two infraorders I studied only various representatives. The species of freshwater and land planarians which were studied by specimen examination will be mentioned in the relevant sections discussing the distribution of particular character states.

The methodology applied in the present study concerns the phylogenetic technique developed by Hennig (1966). The theory and practical application of phylogenetic systematics have been amply discussed in recent literature and it suffices to refer to Wiley (1981), Saether (1983), Hennig (1984), and Ax (1984). Relative degree of apomorphy and plesiomorphy of characters was determined by outgroup comparison, a technique which has been detailed in Watrous \& Wheeler (1981) and Maddison et al. (1984).

\section{Phylogenetic relationships of the Tricladida}

\section{Relationship between the Tricladida and the Proseriata}

It has long been recognized that triclads and proseriate flatworms share a close relationship (cf. Hofsten, 1907, 1918), but the exact nature of this affinity remained obscure for many years. With the rise of Hennigian phylogenetic systematics it be- came possible to assess more precisely the relationship between these taxa. Ax (1961) and Karling (1974) were the first workers to conclude that the triclads represented the sister group of the Proseriata, both groups constituting the monophylum Seriata. According to Karling (1974) autapomorphic characters for the Seriata are (a) the serial, longitudinal arrangement of testes and vitellaria (yolk follicles), (b) the posteriorly directed tubiform and plicate pharynx, and (c) the elongate body shape (Fig. 1 , characters $1,2,3$ ).

Recently, the phyletic status of the various proseriate taxa within the Seriata has been reexamined by Sopott-Ehlers (1985). She concluded that one of the proseriate taxa, viz. the Bothrioplanida, shares a sistergroup relationship with the Tricladida instead of being closely related to the other members of the Proseriata. According to Sopott-Ehlers all proseriate taxa, excepting the Bothrioplanida, are characterized by secondary absence of rhabdites of the lamellated type, which feature is considered to be an autapomorphy for the taxon Proseriata (Fig. 1, character 4). The Bothrioplanida does not belong to the Proseriata because the former lacks the apomorphic characteristics of the Proseriata and has neither the derived features of any of the proseriate subtaxa (Ehlers 1985: 172).

The Bothrioplanida and the Tricladida, on the other hand, share (a) the tricladoid intestine which runs laterally to the pharynx (Sopott-Ehlers, 1985), (b) the crossing-over of muscle layers at the tip of the pharynx (Steinböck, 1925), and (c) the absence of epidermal collar-receptors (Sopott-Ehlers, 1985). The phylogenetic importance of these lastmentioned characters will be discussed in the following sections.

\section{On the phyletic status of Bothrioplana semperi}

Bothrioplana semperi, representing the single member of the family Bothrioplanidae, has always been thought to be very closely related to the triclads (cf. Vejdovsky, 1895; Hofsten, 1907). Most workers, however, assigned Bothrioplana to the Proseriata, although its proper taxonomic position remained problematic. 


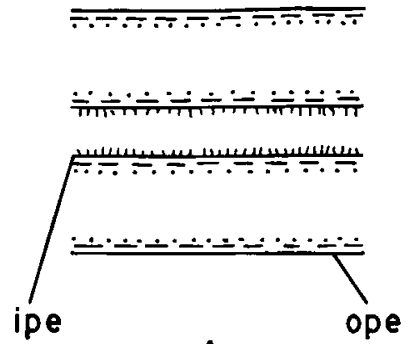

A

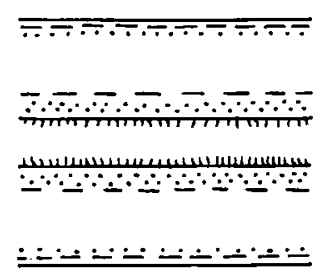

B

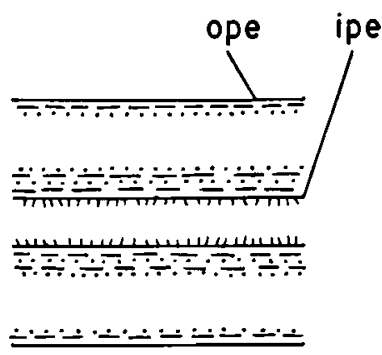

C

Fig. 2. Diagrammatic sagittal view of pharynx musculature. A: Proseriata and Caspioplana pharyngosa, B: planariid type, C: dendrocoelid type. Longitudinal muscle fibers indicated by short horizontal lines, circular muscle fibers by dots. Abbreviations: ipe, inner pharynx epithelium; ope, outer pharynx epithelium.

The presence of the typical tripartite configuration of the intestine of planarians usually has been considered a very characteristic, apomorphic character of the Tricladida (cf. Karling, 1974; Ball, 1981). However, this neat picture has always been confounded by the presence of a tricladoid intestinal system in B. semperi (cf. Sluys \& Ball, 1985). Moreover, in both Bothrioplana and triclads the posterior intestinal branches run laterally to the pharyngeal pouch, in contrast to the Proseriata where the gut trunk runs dorsally to the pharynx (Sopott-Ehlers, 1985). In Bothrioplana the posterior rami of the intestine unite in the hind end of the body to form a single branch, but this is known also from some marine triclads (e.g. Syncoelidium pellucidum, Procerodes trigonocephala, Procerodes harmsi) and from some freshwater planarians such as Dendrocoelum mrazeki, D. infernale, and D. album (cf. Bresslau, 1933: 103). In view of this, it seems indeed justified to postulate that the tricladoid intestine represents a synapomorphy of $B$. semperi and the triclads, as has been done by Sopott-Ehlers (1985). This implies that the trifurcate intestine represents a plesiomorphic character for the Tricladida.

Nevertheless, Sopott-Ehlers (1985) still postulates that the tricladoid intestine forms a synapomorphy for the triclads. In support of that viewpoint she argues that for triclads it is characteristic that the two caudal gut branches do not meet in the hind end of the body and that the exceptions to the rule are the result of secondary change.
However, anastomoses between the posterior intestinal branches occur quite frequently in marine and freshwater planarians; there appears to be very little constraint on either the acquisition or the loss of this feature. Therefore, I consider presence or absence of a connection between the posterior intestinal rami to be a very weak character on this level of the phylogenetic analysis. In view of this, I support Sopott-Ehlers' (1985) suggestion that the tripartite intestinal system is a synapomorphy for Bothrioplana and the Tricladida. However, in contrast to the afore-mentioned worker I postulate that the tricladoid intestine forms a symplesiomorphy for the triclads.

The second synapomorphous character for Bothrioplana and the Tricladida mentioned by Sopott-Ehlers (1985) concerns a particular change in the musculature of the pharynx. It has been pointed out by Steinböck (1925) that in both triclads and $B$. semperi a crossing-over of muscle layers takes place at the tip of the pharynx. In Bothrioplana, marine triclads, and freshwater planarians of the families Planariidae and Dugesiidae the musculature of the pharynx is as follows (Fig. 2B): outer longitudinal muscle layer, outer circular muscle layer, inner longitudinal, and inner circular muscle layer. Kenk (1930) has called this the planariid type of pharynx. In freshwater planarians of the family Dendrocoelidae the situation is somewhat different in that the inner zone of muscles of the pharynx consists of alternating rows of circular and longitudinal muscle fibers (Fig. 2C). In 
land planarians the inner zone of pharynx muscles shows a great complexity and variability between species. This zone may, for example, consist of alternating rows of circular and longitudinal fibers, of interwoven circular and longitudinal muscle fibers, of interwoven fibers with just beneath the epithelium a thin layer of longitudinal fibers, or of rows of circular muscle fibers of which only the innermost ones are interwoven with longitudinal running fibers (Graff, 1912-1917). In the Proseriata there is no change of muscle layers at the tip of the pharynx, the arrangement of the layers being as follows: outer longitudinal muscle layer, outer circular muscle layer, inner circular muscle layer, and inner longitudinal muscle layer (Fig. 2A).

The change of muscle layers at the tip of the pharynx must be distinguished from the 'Schichtenwechsel' that may occur at its root. The result of the last-mentioned change is that the outer pharynx musculature does not match the arrangement of the muscle layers underneath the body wall, i.e., the longitudinal muscles are now situated directly underneath the outer pharynx epithelium, whereas the circular muscles lie entally to the longitudinal muscle layer. This change in configuration at the root of the pharynx occurs in many flatworms, viz. polyclads, Seriata, some cylindrostomids, many plagiostomids (Karling, 1940), and also in several typhloplanids (cf. Luther, 1963; Karling \& MackFira, 1973; Rieger, 1974), and in the Dalyelliidae (cf. Luther, 1955).

Thus, the character state mentioned by Steinböck (1925) and Sopott-Ehlers (1985) in support of a close relationship between Bothrioplana and the Tricladida involves changes of muscle layers both at the root and the tip of the pharynx. This particular type of crossing-over is not at all uncommon among the platyhelminths since it occurs in dalyelliids (cf. Luther, 1955), kalyptorhynchids (cf. Karling, 1931, 1949; Schockaert and Karling, 1970), and in some typhloplanids (cf. Karling \& Mack-Fira, 1973) and polyclads (cf. Bock, 1913: 303). However, it has been suggested that the various types of composite pharynges may not be homologous organs (Karling, 1974; Ehlers, 1985). Therefore, it may be invalid to compare the unique, tubiform pharynx of the Seriata (cf. Fig. 1, charac- ter 2) with other types of plicate or composite pharynx. Consequently, crossing-over of muscle layers at the tip of the pharynx could indeed very well be an apomorphic feature at the Seriate level of organization (Fig. 1, character 6).

As a synapomorphy for the Tricladida and Bothrioplana Sopott-Ehlers (1985) also mentioned secondary absence of collar-receptors, but she admitted that the presumable absence of these receptors in the two taxa may be based only on lack of sufficient information.

$B$. semperi is characterized by an aberrant, parthenogenetic mode of reproduction (cf. Sluys \& Ball, 1985) and by its four pairs of longitudinal nerve cords (Reisinger, 1925) (Fig. 1, characters 7 and 8).

\section{Monophyly of the Tricladida}

The monophyletic status of the Tricladida is supported by at least one very complex, apomorphic character, viz. a unique embryological development which is completely different from that of close relatives such as the Proseriata and $B$. semperi (Bresslau, 1933; Reisinger, 1940; Thomas, 1986) (Fig. 1, character 9). The most characteristic aspect in the development of triclads concerns a temporary embryonic pharynx (for summaries, see Skaer, 1971; Benazzi \& Gremigni, 1982). This particular mode of development was known already for freshwater triclads at the turn of this century, and later it was established that a similar mode of development occurs in land planarians (Carlé, 1935) and marine triclads (Seilern-Aspang, 1956).

This strong synapomorphous character for triclads has not been discussed in earlier studies dealing with the phyletic status of the Tricladida (cf. Karling, 1974; Ball, 1981), but recently the importance of the embryonic development as a uniquely derived character has been mentioned by Sopott-Ehlers (1985) and Ehlers (1985).

Several other synapomorphies of the triclads also have been mentioned in the literature, viz. cerebral position of the female gonads (Steinböck, 1925; Karling, 1974; Ball, 1981; Sopott-Ehlers, 1985; Ehlers, 1985; Fig. 1, character 10), serial arrangement 
of many nephridiopores (Sopott-Ehlers, 1985; Ehlers, 1985; Fig. 1, character 11).

Character 10 concerns the situation that in many triclads the ovaries are situated directly behind the brain. It was already pointed out by Steinböck (1925) that the position of the ovaries is rather variable. In marine triclads, for example, the ovaries may be situated at a short distance behind the brain, half-way between the brain and the root of the pharynx, near the root of the pharynx, or even behind the pharyngeal cavity. According to Steinböck this variable position of the female gonads does not necessarily reduce the value of character 10 if the ovaries are situated at the anterior end of the oviducts. Steinböck's remark probably led Ehlers (1985) to reformulate character 10 as follows: 'both germaria [ovaries] constantly at the beginning of the germo-vitello-ducts [oviducts], i.e. near the brain'. But Steinböck (1925) also already pointed out, in referring to Graff (1912-1917), that in several triclads the oviducts extend anteriorly to the ovaries. This holds true especially for some triclads in which the ovaries are situated at some distance behind the brain, such as Cercyra hastata, Rhodax evelinae, Oahuhawaiiana kazukolinda. But also in Bdellasimilis barwicki, in which the ovaries occur directly behind the brain, there is a branch of the oviducts extending anterior to the germaria. On the other hand, there are also marine triclads with rather backwards situated ovaries (e.g. Procerodes kerguelenensis, Oregoniplana opisthopora, Pentacoelum punctatum, Bdelloura candida), which do not possess the anterior oviduct branch. Therefore, I suggest that the position of the ovaries should be weighted independently of the course of the oviducts.

In the Terricola and the Paludicola the position of the ovaries is less variable than in the Maricola (Graff, 1912-1917; Meixner, 1928).

In view of the above, I propose that the cerebral position of the germaria represents a synapomorphy for the triclads (Fig. 1, character 10), thus endorsing the suggestions of previous workers. Deviations from this groundplan, consequently, are hypothesized to be the result of secondary change instead of the retention of the primitive character state.

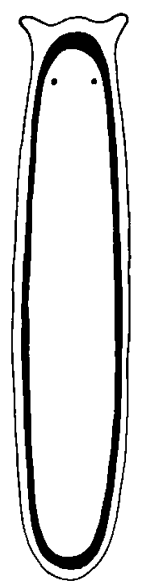

Fig. 3. Ventral view of a planarian; marginal adhesive zone indicated by black band.

Concerning the excretory system, the presence of one pair of ventrally situated nephridiopores represents the primitive condition within the Platyhelminthes (Meixner, 1938; Ehlers, 1985). This plesiomorphous condition is present, for example, in $B$. semperi. In other flatworms, however, the number of nephridiopores may be increased. In some proseriates several nephridiopores may be present, on the dorsal as well as on the ventral body surface (Hofsten, 1907, 1918; Hyman, 1951 ; contra SopottEhlers, 1985: 164), but the greatest increase in number of excretion pores occurs in triclads. In planarians there may be numerous (up to several hundred) pores on the dorsal and the ventral body surface, arranged in a pseudometameric way (Wilhelmi, 1909; Meixner, 1938; Hyman, 1951), which is here postulated as a synapomorphy for the Tricladida (Fig. 1, character 11). To the best of my knowledge, data on the number of nephridiopores in triclads only stem from studies done on either freshwater triclads or on marine planarians, so that the Terricola remain to be tested in this respect.

There is another synapomorphy for the triclads, in addition to the three mentioned above. It concerns the way in which the openings of adhesive glands are arranged on the ventral body surface (Fig. 1, character 12). These openings are situated in a marginal adhesive zone, which forms a ring on the ventral body surface, near the margin of the body (Fig. 3). This annular zone of adhesive gland 
openings is unique to the triclads because in other flatworms the openings of the glands have a much more irregular distribution. In the majority of the otoplanids adhesive glands are confined to the posterior body region (Ax, 1956), and also in other proseriate taxa the arrangement of the openings is totally different from that of triclads. For example, in the Coelogynoporidae the adhesive papillae through which the secretion of adhesive glands is discharged - are arranged into 'Haftfelder' which usually are distributed irregularly on the sides of the body; in some coelogynoporids these 'Haftfelder' are arranged into irregularly running longitudinal rows (Tajika, 1982a).

\section{Phylogenetic relationships within the Tricladida}

(a) Monophyly of the Maricola and phylogeny of the infraorders

According to the phylogenetic hypothesis put forward here (See Fig. 1), the marine triclads were the first to branch off from the main stem, whereas subsequently the land planarians and the freshwater triclads evolved.

In general (but see Wilhelmi, 1909: 386), the monophyletic origin of the marine triclads has been accepted, implicitly or explicitly, by numerous workers. But autapomorphous characters supporting this assumption remained to be discovered, as has been pointed out by Ball (1977a, 1981). It is here hypothesized that the presence of adhesive papillae which are arranged in a marginal band, is a synapomorphy for the marine triclads (Fig. 1, character 13).

For marine triclads adhesive papillae or 'Haftpapillen' were described and depicted already in 1863 by Claparède and in 1881 by Lang. When studied under the light microscope these Haftpapillen appear as small brush-like or mushroomshaped structures which project above the epidermis (Fig. 4). Through these Haftpapillen is discharged the secretion of adhesive glands, which were mentioned already above. The ultrastructure of the adhesive papillae of marine triclads, among others, has been studied by Tyler (1976). It appeared that each adhesive papilla-complex consists of a so-called anchor cell and two types of gland cells, the 'necks' of the latter forming the brush-like projections. For adhesive organs with two types of gland cells Tyler (1976) coined the name duo-gland adhesive system.

Duo-gland adhesive cells are known from many groups of flatworms, and it has been hypothesized that this character forms a synapomorphy for the large taxon Rhabditophora (Ehlers, 1985). From light microscopical studies it was already known that the Haftpapillen of the Proseriata are very similar to those of the marine triclads and ultrastructural investigations have supported these findings (Tyler, 1976). But neither in the proseriates, nor in any other taxon of the Rhabditophora are the Haftpapillen arranged in a marginal adhesive zone, as is the case in the Maricola. This adhesive band is about four anchor cells wide, i.e. there are about four Haftpapillen situated side by side.

Thus, for the marine triclads it is not the mere presence of Haftpapillen which represents their synapomorphous character, but it is the arrangement of the Haftpapillen in a marginal band which is uniquely derived for the Maricola.

In freshwater and land planarians the marginal band of adhesive cells is present also (Fig. 1, character 12) but it is of a different structure. In the Terricola and the Paludicola there are no Haftpapillen and the secretion of the adhesive glands is discharged through the epidermal cells. Since it is highly likely that the common ancestor of the Seriata possessed Haftpapillen, the absence of the latter in Terricola and Paludicola represents a case of secondary loss, which is here hypothesized to be a synapomorphy for these two groups (Fig. 1, character 14).

That the common ancestor of the Seriata had Haftpapillen is based on the hypothesis that these structures arose in the ancestor common to the Seriata, Typhloplanida, Kalyptorhynchia, Dalyellioi$\mathrm{da}$, and the parasitic flatworms. Absence of Haftpapillen in the Dalyellioida and the parasitic flatworms is then explained by secondary loss in their common ancestor. Haftpapillen and the duo-gland adhesive system are absent in the Catenulida, Nemertodermatida, Acoela, Lecithoepitheliata, and Prolecithophora. Polyclads and macrostomids, the primitive members of the Rhabditophora 


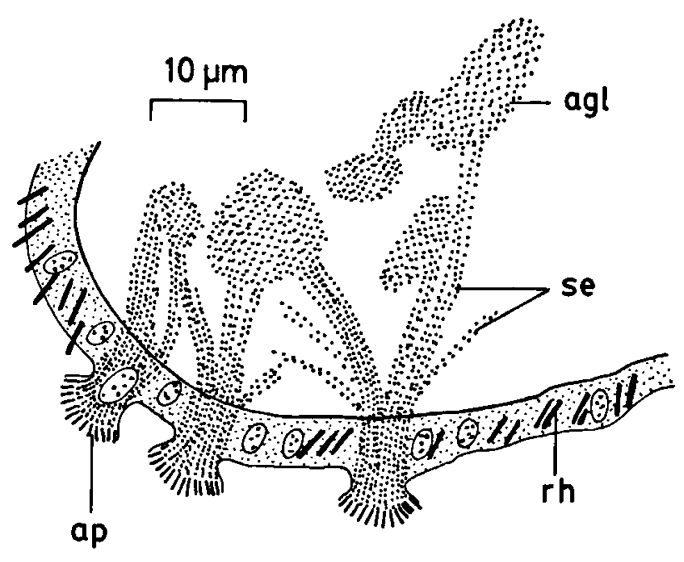

Fig. 4. Transverse section through the adhesive papillae of $\mathrm{Cer}$ cyra hastata, as seen through the light microscope. Abbreviations: agl, adhesive glands; ap, adhesive papilla; rh, rhabdite; se, secretion.

(cf. Ehlers, 1985: 168), do possess the duo-gland adhesive system, but the secretions are discharged via Haftpapillen different from those of the proseriates, triclads, and rhabdocoels (cf. Tyler, 1976).

In the Paludicola the marginal adhesive zone has the same function as in marine triclads, i.e. the animals use it for attachment to the substrate during locomotion. But in the Terricola the marginal adhesive zone must have another function, as has been pointed out by Graff (1912-1917), because land planarians use a specialized creeping sole (Fig. 1, character 17) for locomotion.

There is another character supporting the hypothesis that the Terricola and the Paludicola share a unique common ancestor, viz. the presence of resorptive vesicles (Fig. 1, character 15). These vesicles are altered vitellarian follicles which function in the resorption of excess sperm. Recently, such resorptive vesicles were described, independently of previous studies, for Bdellasimilis barwicki (Sluys \& Ball, 1989), a species of which the phyletic status is still uncertain. In the course of the present study a literature search learned that similar structures, with a similar function, have been reported for freshwater and land planarians. Cernosvitov (1931), in his study on sperm resorption in triclads, mentions several authors who observed sperm in the ventral, vacuolated portion of the vitellaria of various species of freshwater planarians. The same worker observed that within the large vacuoles ('Dotterkammern') of the vitellaria degeneration and resorption of spermatozoa take place. According to the information provided by Cernosvitov (1931) resorptive vitellarian follicles occur in the following species of freshwater planarians: Dugesia gonocephala, D. polychroa, D. burmaensis, Dendrocoelum lacteum (see also Kaburaki, 1918, 1922), Phagocata paravitta, $P$. armeniaca, D. album, D. subterraneum, Planaria torva, Bdellocephala schneideri, and Baikalobia raddei. Resorptive vesicles have also been described for Dugesia annandalei (Kaburaki, 1918). In more recent literature similar structures were described for Neppia schubarti (Marcus, 1946), Dendrocoelum maculatum, D. sanctinaumi, Phagocata ochridana, and P. leptophallus (Reisinger, 1963; Kenk, 1978). In the two last-mentioned species the vacuolated portion of the vitellarian follicles is developed to such an extent that they have been referred to as accessory receptacula seminis (cf. Reisinger, 1963, Fig. 2). I observed resorptive follicles also in Spathula camara and in another, still undescribed species of Spathula.

Concerning the Terricola, resorptive vesicles have been described for Kontikia orana (cf. Froehlich, 1955; Winsor, 1986), and similar structures were reported for Bipalium ephippium, Pelmatoplana sondaica, Geoplana nasuta (cf. Loman, 1890), and G. sieboldi (cf. Krsmanovic, 1898). Reexamination of $K$. bulbosa revealed that resorptive vesicles are present also in this species.

Because I have never observed resorptive vesicles in marine triclads, it is here hypothesized that these vesicles are a synapomorphy for the Terricola and the Paludicola.

The third synapomorphy for the Terricola and Paludicola is the secondary reduction of the number of longitudinal nerve cords (Fig. 1, character 16), which will be illustrated in the following section on the monophyletic origin of the land planarians. Concerning this reduction of nerve cords, a parallel development is seen in the Otoplanidae, in which there are also forms that show the derived condition of two pairs of nerve trunks or of only one pair of main nerve cords (Ax, 1956). 

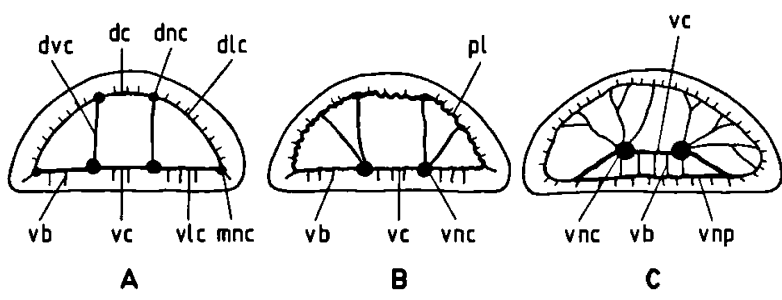

Fig. 5. Diagrammatic transverse sections showing the nervous system. A: Maricola, B: Paludicola, and C: Terricola (modified from Meixner, 1928). Abbreviations: dc, dorsal commissure; dlc, dorso-lateral commissure; dnc, dorsal nerve cord; dvc, dorso-ventral commissure; mnc, marginal nerve cord; pl, plexus; vb, ventral bridge; vc, ventral commissure; vlc, ventrolateral commissure; vnc, ventral nerve cord; vnp, ventral nerve plexus.

\section{(b) Monophyly of the Terricola}

The monophyletic status of the Terricola is supported by the following autapomorphies: (1) presence of a creeping sole (Fig. 1, character 17); (2) different type of pharyngeal musculature, as compared with the Maricola and Paludicola (character 18), and (3) diploneuran nervous system (character 19).

The term creeping sole is here used in a very broad sense, referring to the complex, protruding type as well as to the very simple, flat type of creeping sole as found in the Geoplanidae (cf. Graff, 1899, 1912-1917).

In the above (p. 7) mention was already made of the complex and different type of pharynx musculature, which is here proposed as a synapomorphy for the terricolans.

The different structure of the terricolan nervous system and its taxonomic value were discussed in detail by Steinböck (1925). He noted that the nervous system of the Terricola differs from both the Maricola and the Paludicola.

In the Maricola the nervous system consists of a number of bilaterally arranged longitudinal nerve cords, connected through various commissures (Fig. 5A). Further, a fine nerve plexus is situated just beneath the basement membrane of the epidermis, forming the subepidermal nerve plexus. Actually, the marginal nerve is part of this nerve plexus and it is morphologically different from the other nerve trunks. Especially the ventral subepidermal nerve plexus is connected with the ventral nerve cords and commissures by means of short and thin bundles of nerve fibers, or so-called 'ventral bridges'. The situation with three pairs of longitudinal nerve trunks is presumed to be the primitive condition within the Tricladida, since a similar configuration is characteristic of, at least, the Otoplanidae (Ax, 1956).

In the Paludicola (Fig. 5B), the situation is somewhat different in that the dorsal and lateral pairs of longitudinal nerve cords are very inconspicuous or almost absent, i.e. their nerve fibers have joined the commissures to form a sort of plexus.

In the Terricola only the pair of ventral nerve cords is present, whereas the fibers of the other longitudinal nerve cords and those of the commissures form a close-meshed plexus. In the land planarians the ventral subepidermal nerve plexus is highly developed, which probably relates to the presence of a creeping sole. As in the Paludicola and the Maricola the ventral subepidermal nerve plexus of the Terricola is connected with the ventral nerve cords and the ventral commissure through ventral bridges. In the Terricola the pair of ventral nerve cords takes a much more internal position in the body, as compared with the Maricola and Paludicola. The nervous system of the Terricola has been called the diploneuran nervous system (Steinböck, 1925).

The interpretation of the similarities and differences between the nervous systems of the three triclad infraorders, as provided above, follows that of Meixner (1928). Steinböck (1925), however, concluded that the ventral nerve cords of the terricolans are not homologous with those of the Paludicola and Maricola. Steinböck followed Graff (1899) in assuming that the nervous system of the flat, neotropical geoplanid Terricola formed the starting point of an evolutionary morphocline. In these particular geoplanids the nervous system consists of a diffuse nerve plexus or nerve plate beneath the gut. In other terricolans fibers and ganglia from the ventral nerve plate would gradually have concentrated to form the two ventral nerve cords, which are present in many land planarians. Connections or commissures between the two ventral nerve cords are supposed to be derivatives of the 


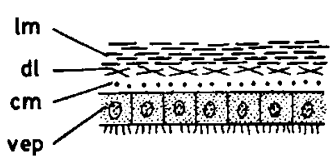

A

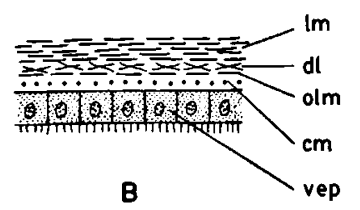

Fig. 6. Subepidermal musculature. A: Proseriata, Maricola, Terricola. B: Paludicola. Abbreviations: $\mathrm{cm}$, circular muscle layer; $\mathrm{dl}$, diagonal muscle layer; $\mathrm{lm}$, longitudinal muscle layer; olm, outer longitudinal muscle layer; vep, ventral epidermis.

nerve plate and, consequently, are supposed to be different from the ventral commissures in the Paludicola and Maricola.

I do not think that there is any evidence that Graff's morphocline concerning the nervous system in the Terricola is polarized from an evolutionary, phylogenetic perspective. Moreover, there is ample morphological evidence (see above) that the ventral nerve cords of the Terricola are homologous with those of the Maricola and Paludicola. Therefore, it is here hypothesized that the diploneuran nervous system only represents a quantitative differentiation, as compared with the Maricola and Paludicola. In the land planarians the number of nerve cords is reduced, whereas the ventral subepidermal nerve plexus is highly developed. Although the differences with the Paludicola and Maricola are only quantitative in nature and not qualitative, i.e. not concerning entirely new structures, it is still true that the nervous system of the Terricola has a very characteristic and different shape. Therefore, the diploneuran nervous system is still hypothesized to be an autapomorphy for the Terricola (Fig. 1, character 19).

\section{(c) Monophyly of the Paludicola}

The unique common ancestry of the freshwater triclads is based on the following synapomorphies: (a) subepidermal musculature consisting of four layers (Fig. 1, character 20); (b) sperm transfer through spermatophores (character 21); and (c) probursal condition (character 22).

In the Proseriata, Bothrioplanida, and the Maricola the subepidermal musculature consists of an outer, subepidermal layer of circular muscles and an inner layer of longitudinal muscles. For at least the Otoplanidae and the Maricola it has been established that between these two muscle layers is inter- polated a very thin layer of diagonally arranged muscle fibers. This diagonal muscle layer consists of two, crosswise arranged, rows of fibers and is usually difficult to observe. According to Graff (1912-1917: 2746), the subepidermal musculature of the Terricola shows the same layers, although each of them may be developed to an extent never found in the Maricola or Proseriata (Fig. 6A).

In freshwater planarians there is an extra, longitudinal muscle layer interpolated between the circular and the diagonal muscle layer, as was already pointed out by Meixner (1928). This means that the subepidermal musculature of freshwater planarians consists of the following layers (Fig. 6B): layer of circular muscles directly beneath the basement membrane, thin layer of (outer) longitudinal muscles, diagonal layer, and (inner) longitudinal muscle layer. The extra layer of outer longitudinal muscles is very thin, consisting of only one row of fibers, and it is usually difficult to discern. Moreover, this layer may not be present on every part of the body.

Generally, modern triclad specialists pay little attention to the subepidermal musculature and, consequently, their species descriptions do not give any information on the presence or absence of the outer longitudinal muscle layer. In some of the older publications mention is explicitly made of the presence of this thin muscle layer, e.g. Neppi (1904) but also Marcus (1955) for Dugesia neumanni, Seidl (1911) for Polycelis sabussowi, Korotneff (1912, cited in Graff, 1912-1917) for Sorocelis, Kenk (1925) and Dahm (1960) for Dendrocoelopsis, and Graff (1912-1917) concerning references involving other species.

The very indistinct nature of the outer longitudinal muscle layer probably accounts for the fact (1) that I observed this layer in some specimens of a Paludicolan species, whereas I failed to discern it in other specimens of the same species, and (2) that for some species there are discrepancies between my observations and statements in the literature. As examples of the last-mentioned point I mention the following cases. Weiss (1910) apparently did not observe the outer longitudinal muscle layer in Dugesia hoernesi, D. boehmigi, and D. graffi, whereas I observed this muscle layer in the material prepared by the aforementioned worker. According to Ball (1970) the outer longitudinal muscle 
layer would be absent in Dugesia nannophallus and in $D$. batuensis. However, examination of new material revealed that this fourth muscle layer is also present in these two species.

I found the outer longitudinal muscle layer to be present also in specimens of the following species: Cura pinguis, C. patagonica, Dugesia andina, $D$. lugubris, Bdellocephala brunnea (from Russia), Sorocelis hepatizon, and an unidentified Dugesia (Girardia) species from Colombia.

It is evident that within the Paludicola the character of the outer longitudinal muscle layer deserves much more attention than it receives at present. The distribution of this character should be checked carefully over the various paludicolan taxa. Pending further information, the phylogenetic hypothesis proposed here assumes the outer longitudinal muscle layer to be a synapomorphy for the freshwater triclads (Fig. 1, character 20).

During the copulation of marine triclads free sperm is discharged into the partner, whereas in the Paludicola as a rule sperm is transferred by means of spermatophores. With respect to the freshwater planarians, presence of spermatophores has been mentioned for species of the genera Dugesia, Planaria, Polycelis (cf. Weiss, 1910; Graff, 19121917; Kaburaki, 1917, 1918; Reisinger, 1923), Phagocata (Kaburaki, 1917; Okugawa, 1939), and Neppia (Marcus, 1955, 1970; cf. Ball, 1974c). Further, I observed a spermatophore in the bursal canal of an unidentified species of Spathula from Australia. The more or less sclerotized wall of these spermatophores is formed by the secretion of glands in the penis. An exception may be formed by Dugesia seclusa in which only 'free sperms' were observed in a spacious chamber in the penis papilla and in the copulatory bursa (Sluys \& De Vries, 1988).

Spermatophores are thought to be absent in the Terricola (Meixner, 1928), but Heinzel (1929) observed a spermatophore-like structure in the atrium of Platydemus victoriae. Pending further studies it is here hypothesized that sperm transfer through spermatophores forms a synapomorphous character for the freshwater planarians (Fig. 1, character 21).

In general, freshwater triclads have the copulato- ry bursa in front of the male copulatory apparatus (Fig. 1, character 22), whereas in the Maricola the bursa is situated behind it, the latter condition being the primitive situation within the Tricladida. The probursal condition appears to apply well for the Paludicola as defined in this study (see Fig. 1), excepting those species in which a copulatory bursa is completely absent. In view of the fact that a copulatory bursa is considered to be a basic structure in the organization of flatworms (Remane, 1951), absence of the bursa is here assumed to be the result of secondary loss, which has occurred independently in the Paludicola, Maricola and Terricola.

\section{(d) Relationships within the infraorders}

In his study of the Paludicola and the Dugesiidae in particular, Ball (1974a) suggested that the Dendrocoelidae could be characterized by two apomorphies, viz. the different type of inner pharyngeal musculature, as compared with other planarians (Fig. 2C; Fig. 1, character 25), and the presence of anterior adhesive organs (Fig. 1, character 26). In this particular study Ball (1974a) failed to find defining, autapomorphous features for the Planariidae and the Dugesiidae, but in later publications (Ball, 1974b, c) he noted that the Dugesiidae were characterized by a peculiar eye structure (Fig. 1, character 23). In the Dugesiidae the pigment cup is multicellular, and contains numerous retinal cells (cf. Ball, 1981, Fig. 4D). This contrasts strongly with the unicellular eye cups with usually only a few retinal cells which are found in the Maricola and the non-Dugesiid members of the Paludicola. The Terricola complicate the picture in that multicellular eye cups with numerous retinal cells are found also in land planarians. However, the dugesiid eye differs from the types of eye found in the land planarians in that in the former the dendrites enter the eye cup via its opening, thus penetrating the corneal membrane, whereas in the Terricola the dendrites enter through the openings between the pigment cells (cf. Hesse, 1902). Autapomorphies defining the Planariidae remain to be discovered.

That the Planariidae and the Dendrocoelidae share a sistergroup relationship is suggested by the 
fact that in these taxa the common oviduct opens into the atrium (Fig. 1, character 24), whereas the Dugesiidae show the plesiomorphous condition in which the oviducts communicate, separately or combined, with the bursal canal (Ball, 1974a, 1981). Although I agree with Ball's conclusion I wish to elaborate on the reasoning that led me to endorse his hypothesis because it differs somewhat from his argumentation.

The condition wherein the oviducts unite to form a common oviduct which, after receiving the secretion of shell glands, opens into the genital atrium, occurs in many platyhelminth taxa and forms without doubt a primitive character for many phylogenetic groups. However, in the particular case considered here it is probably much more relevant to compare the Paludicola with those functional outgroups which possess a copulatory bursa and bursal canal comparable to those of triclads. It is the 'association' (Ball, 1974a: 344) of oviducts and bursal canal that is here at stake. Under the present hypothesis functional outgroups are to be found among the land planarians, the marine triclads, and the proseriates.

According to Ball (1974a: 344$)$ in proseriates the oviducts 'are usually associated with the bursal stalk or equivalent female genital canal'. Due to its generality, however, this statement is incorrect. In otoplanids there is no association between the common oviduct, which receives the secretion of shell glands close to its opening into the atrium, and the bursal canal. On the contrary, there is a distinct separation between the openings of the common oviduct and the bursal canal into the genital atrium (cf. Ax, 1956). In coelogynoporids the oviducts open into the distal part of the female genital duct, which may be developed to greater or lesser extent (Tajika, 1982a). According to Tajika (1982a) the female genital duct results from fusion of the two oviducts, so that actually it is a common oviduct, the histology of which is different from that of the genital atrium. This female genital duct receives the openings of shell glands. Posterior (= entally) to the point where the oviducts unite to form the female genital duct, the latter communicates with the bursal canal or with the genito-intestinal duct, structures which are present in many coelogyno- porids. Tajika (1982a) points out that with respect to the female genital duct, shell glands, and oviducts the situation in the Coelogynoporidae is essentially conform to Meixner's (1928) type I organization in triclads. This would indeed imply that for the triclads type $I$ is primitive and that the condition in which the common oviduct opens into the atrium is derived, as suggested by Ball (1974a). But if we consider the Otoplanidae the character state polarity would be reversed! Consequently, assessment of character state polarity based on distribution of states in the Proseriata, is equivocal.

Reference to the Maricola and, more importantly, to the Terricola enables us to reach a decisive polarity assessment. In the Maricola the oviducts generally communicate, separately or combined, with the bursal canal or equivalent duct, which also receives the openings of the shell glands. In terricolans with a copulatory bursa the oviducts communicate, separately or combined, with the bursal canal; the oviducts and/or bursal canal receive the secretion of shell glands. Because in the Terricola and in the Maricola the oviducts are 'associated', i.e. communicate with the bursal canal, the condition in which the common oviduct opens into the genital atrium forms indeed a synapomorphy for the Dendrocoelidae and the Planariidae (Fig. 1, character 24), as proposed by Ball (1974a).

It must be noted that there is a vexed issue in the platyhelminth literature which has become known as the bursa problem (cf. Steinböck, 1924, 1966). In the present context the bursa problem relates to the question whether the bursa and bursal canal in triclads are really homologous with similar structures in the proseriates. If it can be shown that there is no homologous relationship then the comparison, in this respect, between proseriates and triclads becomes irrelevant.

The intrafamilial relationships of the Dugesiidae have been studied by Ball $(1974 a, c)$, but the Planariidae and the Dendrocoelidae have never been subjected to a detailed phylogenetic analysis.

Phylogenetic relationships among the land planarians are still to be studied, but in view of the copulatory apparatus it is likely that the Microplaninae are the most primitive taxon in the Terricola, as was suggested by Marcus (1953) and Froehlich 
(1967). The copulatory apparatus of many microplanids resembles more or less that of the Maricola. As examples I mention Microplana scharffi and $M$. terrestris (cf. Ball \& Reynoldson, 1981), $M$. monacensis (cf. De Beauchamp, 1961, Fig. 59A), and also M. aberana (cf. Mell, 1904) and $M$. henrici (cf. Minelli, 1977).

The phylogenetic relationships within the Maricola are the subject of an ongoing study of the present author.

\section{Discussion}

With respect to relationships within the Tricladida the results of the present study are more or less compatible with suggestions expressed by the few workers who have given this subject detailed attention (cf. Meixner, 1928; Ball, 1981). The present treatment differs from previous studies in that it provides a more rigorous, broader data base in support of the proposed phylogenetic hypothesis, and that it results in the recognition of monophyletic groups which previously were either poorly defined or not defined at all by apomorphic characters.

The phylogenetic hypothesis formulated in this study attempts to minimize the number of ad hoc assumptions concerning parallel and convergent evolution. Nevertheless, the phylogenetic tree presented (Fig. 1) still subsumes a number of interesting cases of parallelism as well as a few confounding instances of supposedly independent development, of which some were already mentioned in previous sections. A few other cases of parallelism will be detailed below. Furthermore, attention will be paid to a few characteristics to which phylogenetic importance has been assigned in previous studies, but which have not been used in the construction of the phylogenetic tree here presented.

\section{Precerebral coecum}

One case of parallelism concerns the situation that in triclads the anteriorly running gut trunk may either extend in front of the eyes or terminate just behind the eye cups. It has been postulated that the latter condition, i.e. the reduction of the anterior gut trunk forms a derived character for the Paludicola (Meixner, 1928; Ball, 1981).

As a short digression I mention here that in species descriptions of planarians usually mention is made of extension of the gut beyond the eyes but that it is preferable to use the brain as a reference point and to speak of the presence or absence of a precerebral coecum. This means that the character states can be scored also for triclads which lack eyes and can be compared with outgroups in which eyes are also absent. Since at least in marine triclads the eyes are usually situated dorsally to the brain there is in this group an almost exact synonymy between the character state precerebral coecum and 'extension of the anterior gut trunk in front of the eyes'. The precerebral coecum has also been referred to as cephalic duct.

It was already pointed out by Meixner (1928) that the Maricola usually have a precerebral coecum whereas such a structure is absent in the Paludicola, according to the same worker. In Meixner's view the triclads evolved from otoplanid-like ancestors and therefore he homologized the precerebral coecum of the Maricola with the 'Kopfdarm' (= precerebral coecum) of the Otoplanidae. According to Meixner the Maricola are characterized by a further development of the precerebral coecum and the Paludicola by a reduction of the latter. However, present information indicates that evaluation of the presence or absence of a precerebral coecum in triclads is now more complex than suggested by Meixner (1928).

In otoplanids and coelogynoporids the histology of the precerebral coecum is different from that of the rest of the intestine in that usually it shows no lumen but is filled with cells or with a syncytial mass. In that respect Meixner may still be correct in his suggestion that the Maricola show a derived condition of the precerebral coecum because in these planarians it functions as a proper part of the intestine, while its histology is similar to the rest of the gut. But when more taxa within the Seriata are taken into account assessment of homology and of the primitive or derived status of the precerebral coecum becomes less clear.

In the Bothrioplanida and the Otomesostomidae 
the intestine does not extend in front of the brain (cf. Hofsten, 1907; Sluys \& Ball, 1985). In the majority of species of the Monocelididae the gut terminates dorsally to the brain but in the genera Asilomaria and Archimonocelis the intestine forms a precerebral diverticulum (Karling, 1967; Tajika, 1981). The Nematoplanidae do have a precerebral coecum which in some species communicates with the intestine, but in others it does not so. Moreover, it is not certain whether the precerebral coecum of the Nematoplanidae is derived from the intestine or from chordoid tissue which builds also the chorda intestinalis in these animals (cf. Meixner, 1938; Tajika, 1979, 1982b). Thus, it may be that at least the precerebral coecum of the Nematoplanidae is non-homologous with that of the Maricola. According to Ax (1957) the chordoid precerebral coecum, which is devoid of a lumen, originated from the intestine independently of the similar origin of the precerebral coecum with a resorptive function. Therefore, Ax (1957) denies a homologous relationship between the chordoid precerebral coecum of proseriates and the 'Kopfdarm' of other platyhelminths.

It is clear that presence or absence of a precerebral coecum are character states which are variable in the Proseriata. But also within the Tricladida there is variability. With respect to land planarians a precerebral coecum may be present in one species and absent in another, but the distribution of the character states over the species(groups) is less wellknown than in the Maricola and the Paludicola. Although Meixner (1928) was correct in his statement that the majority of species of marine triclads show a precerebral coecum it is also true that there are several maricolans which lack the cephalic duct, e.g. Procerodes kerguelenensis, Micaplana misae, Cercyra teissieri, Puiteca rigida, Bdelloura candi$d a, B$. propinqua, and Syncoelidium pellucidum. And Meixner's conclusion that the Paludicola are characterized by a reduced cephalic duct has lost its general validity because it is now known that there are Tasmanian and Australian paludicolans with a distinct precerebral coecum, e.g. Spathula truculenta, $S$. gourbaultae, $S$. fontinalis, $S$. tryssa (cf. Ball, $1977 \mathrm{c}$ ), S. dittae, and S. ochyra (cf. Ball \& Tran, 1979), Eviella hynesae (cf. Ball, 1977d).
Actually, there are more Australian and Tasmanian freshwater planarians with a precerebral coecum than is apparent from the literature. In the descriptions of these species the forward extension of the anterior gut trunk is being assessed relative to the position of the eyes. However, examination of specimens of several of these species showed that in the genera Spathula and Romankenkius the eyes are situated anteriorly to the brain and not directly dorsally to the brain, as in marine triclads. This implies that in species for which it is mentioned that the anterior gut trunk extends to or between the eyes it may well be the case that the gut forms a cephalic duct. For example, in Romankenkius $k e n k i$, for which it is mentioned that 'the anterior ramus of the intestine extends forwards to the level of the eyes' (Ball, 1974c: 7), the eyes are situated far in front of the brain, so that the species actually possesses a well-developed precerebral coecum.

Because presence or absence of a cephalic duct is variable in the ingroup and the outgroups, assessment of relative apomorphy or plesiomorphy of the character states becomes arbitrary for the Tricladida. Consequently, the cephalic duct has not been used as an apomorphic feature in the present phylogenetic hypothesis. However, once such an hypothesis has been formulated it may be postulated that the precerebral coecum forms an underlying synapomorphy, supporting the monophyletic status of the Seriata.

\section{Probursal condition}

That freshwater triclads usually have the copulatory bursa in front of the male copulatory apparatus is an apomorphic character for the Paludicola, according to the phylogenetic hypothesis formulated above. But there are a few species which confound the picture. The most extreme case is found in the marine triclads Probursa veneris and $P$. moei. In both species the bursa is situated in front of the male copulatory apparatus, just as is the case in many paludicolan planarians. Further, there are several marine triclads in which the bursal canal curves antero-dorsad, with the result that the copulatory bursa lies above the male atrium or above the 
genital duct, e.g. Cercyra hastata, Obrimoposthia wandeli, Pacifides psammophilus. As confounding cases Ball (1981) also mentioned Bdellasimilis barwicki, Eviella hynesae, the genus Opisthobursa, and Balliania thetisae. However, these four cases may not be too problematical after all. In the first place, the copulatory bursae of Bdellasimilis and Eviella are no true bursae since in the first-mentioned species the supposed bursa concerns an accumulation of resorptive vesicles (cf. Sluys \& Ball, 1989), whereas in $E$. hynesae the bursa actually is the expanded portion of the female genital duct (Ball, 1977b: 153). Secondly, the taxonomic position of the two species of Opisthobursa, Balliania thetisae and similar species like Rhodax evelinae, and Mitchellia sarawakana are still highly problematical. Except for Rhodax, these species have been assigned to the Maricola, but always with many reservations. However, there are also a number of characters which point to a closer relationship with the Paludicola, which would indeed complicate the phylogenetic interpretation of the probursal condition. But in that case, there is always the possibility that the bursa of Opisthobursa, for example, is different from that of other aquatic planarians, as has been pointed out by Ball (1977b: 154).

In contrast to Ball (1981: 10), who stated 'that there are no compelling reasons for assuming the probursal condition of the Paludicola to be uniquely derived', it is here postulated that the probursal condition asserts the unique common ancestry of the Paludicola. The confounding cases of parallelism mentioned above, in particular Probursa, are considered to be the result of independent evolutionary pathways. Species like Probursa veneris, Obrimoposthia wandeli, and Cercyra hastata do possess Haftpapillen and features characteristic of more restrictive groups of marine triclads and because of parsimony these characters have been given priority over the probursal condition.

\section{Pharynx}

It has been postulated that the dendrocoelid type of pharynx represents an autapomorphy for the Den- drocoelidae (Fig. 1, character 25). But there are a number of dendrocoelids in which the muscles of the pharynx are differently arranged, viz. Caspioplana pharyngosa, Polycladodes, Acromyadenium, and the subfamily Kenkiinae. In Caspioplana the pharyngeal musculature conforms to the situation found in the Proseriata (Zabusova, 1951). In Polycladodes and Acromyadenium the outer pharyngeal musculature is different in that it consists of alternating rows of longitudinal and circular muscles (Gourbault, 1972).

The arrangement of pharynx muscles in the paludicolan genus Macrocotyla does not conform to any of the situations depicted in Fig. 2. The difference resides in the inner zone of pharynx muscles. In Macrocotyla this zone consists of two layers, viz. one layer of circular fibers immediately underneath the inner pharynx epithelium and a surrounding layer composed of intermingled circular and longitudinal muscle fibers (Kenk, 1975). It has been debated whether Macrocotyla should be ranked among the dendrocoelids or should be classified in a separate, fourth (sub)family, together with the genera Kenkia and Sphalloplana (cf. Ball, 1974a; Kenk, 1975; Kawakatsu \& Mitchell, 1981). This subfamily Kenkiinae is characterized by the fact that the internal muscle zone of the pharynx consists of two layers, a circular muscle layer directly underneath the inner pharynx epithelium and entally to this layer either longitudinal fibers or intermingled longitudinal and circular muscles.

In the majority of species of the land planarians the pharyngeal musculature is much more complex than in the planariid and the dendrocoelid types of pharynx which occur in the Maricola and Paludicola (see above). Exceptions are formed by some species of the terricolan family Rhynchodemidae such as Microplana henrici and Rhynchodemus (Microplana) richardi, which have a dendrocoelid type of pharynx (cf. Bendl, 1909). In other members of the family, however, the pharynx is neither of the dendrocoelid type nor like that of the planariid type. That a comparison of pharyngeal musculature should take into account not only the inner muscle layers but also the outer zone of muscles is exemplified by the land planarian Microplana purpurea. In this species the inner pharyngeal musculature is 
similar to that of the planariid pharynx but the outer muscle layer is different in that it has an extra row of longitudinal fibers entally to the row of circular muscles (Bendl, 1909).

\section{Reproduction}

According to Calow \& Read (1986) the phylogeny of the Paludicola as proposed by Ball (1981; see also Fig. 1) parallels the trend fissiparity - nonfissiparity. In this section it will be examined whether this trend indeed supports the hypothesis.

Meixner (1928) already mentioned that a characteristic feature of the Maricola is that they reproduce only sexually through the formation of cocoons, in contrast to freshwater triclads which may multiply also through fission. According to the same worker the land planarians usually show a sexual mode of reproduction.

For the Maricola indeed I know of no cases in which animals have been observed to use fissioning as a mode of reproduction, but for the Terricola Graff (1912-1917) already mentioned a few exceptions to the rule. According to this worker, successful cases of fissioning were observed in specimens of Dolichoplana, Pelmatoplana sondaica, and Bipalium kewense. Recently, Makino \& Shirasawa (1986) reported that asexual reproduction occurs also in $B$. nobile and $B$. multilineatum, but that fission is absent in $B$. fuscatum. Ball (pers. comm.) observed fission in a species of Microplana.

Evidence is now accumulating from which it becomes clear that within the Paludicola fission is restricted to the Planariidae and the Dugesiidae and that it does not occur in the Dendrocoelidae (Beveridge, 1982; Calow \& Read, 1986). An exception may be formed by Dendrocoelum lacteum for which Berninger (1911) reported to have observed fissioning, which contrasts with information provided by more recent publications (cf. Ball \& Reynoldson, 1981).

Evaluation of the character state distributions of sexual and asexual reproduction within the scope of the present study is dependent on which state is postulated to be primitive for the Seriata or the Tricladida. According to one hypothesis asexual reproduction is primitive for the Platyhelminthes as a whole (Rieger, 1986), and another hypothesis postulates that asexual reproduction has arisen independently and secondarily in several groups of flatworms (Ax \& Schulz, 1959). The last-mentioned authors specifically mention the Tricladida as a group in which several members have secondarily acquired the asexual mode of reproduction. In view of these conflicting hypotheses it is not easy to evaluate the occurrence of sexual reproduction in the Maricola, the Terricola, and the Dendrocoelidae and the presence of asexual reproduction in the Planariidae, the Dugesiidae, and some terricolans. Since reproduction through fission is not known in the Proseriata I favor the hypothesis that asexual reproduction is a derived condition within the Tricladida. This implies that under the present phylogenetic hypothesis (Fig. 1) sexual reproduction in the Maricola, the Terricola, and the Dendrocoelidae is postulated to result from retention of the primitive character state and that the capacity of fission has evolved independently in several taxa within the Tricladida.

\section{Yolk globules}

According to Gremigni (1979) the proposed relationships between the three paludicolan families (see Fig. 1) is supported by an ultrastructural character, viz. the presence or absence of autosynthetic yolk globules in the oocytes. In the Dugesiidae the oocytes contain yolk globules which are widespread throughout the ooplasm and which are synthesized within the cells, whereas such structures are absent in the Dendrocoelidae and Planariidae. In the two last-mentioned families the oocytes contain a different type of inclusion, viz. cortical granules which are located in a monolayer in the cortical ooplasm.

However, a proper interpretation of the phylogenetic significance of autosynthetic yolk globules within the Tricladida appears not to be feasible at the moment. Apart from problems related to the assessment of homology (cf. Tyler, 1981; Gremigni, 1981) there is as yet not enough information about the distribution of the character states within and outside of the Tricladida. With respect to these yolk 
globules and cortical granules nothing is known about the Terricola, and the few results obtained for the Maricola are difficult to interpret. Gremigni \& Nigro (1983) reported on the presence of autosynthetic yolk globules in the maricolan Cercyra hasta$t a$ but the oocytes of the marine triclads Procerodes lobata and $P$. dohrni contained cortical granules (Gremigni \& Nigro, 1982; Gremigni et al., 1986).

Autosynthetic production of yolk is a primitive character within the Platyhelminthes but before it can be concluded that the Planariidae and the Dendrocoelidae are characterized by the derived absence of yolk globules, i.e. the presence of cortical granules, more information is needed about the character state distributions not only in the Maricola but also in the Terricola and the Proseriata. It appears that the oocytes of at least some Otoplanids also lack yolk globules (Sopott-Ehlers, 1986). The data available at present (cf. Gremigni et al., 1986) point to many cases of parallelism within the Neoophora.

\section{Cocoon shell globules}

Ehlers (1985: 130-132) suggested that the Tricladida may be characterized by cocoon shell globules which are different from those in other taxa of the Neoophora. As a consequence, this different type of cocoon shell globules could be used as an apomorphy for the triclads. However, Ehlers (1985) also pointed out that much more information was needed about taxa within the Tricladida and the Proseriata. In a more recent publication it was indicated that the presumed apomorphy should be used at a higher level of universality because cocoon shell globules may have a similar structure not only in triclads but also in the proseriates, while the Prolecithophora and Rhabdocoela have differently structured globules (Sopott-Ehlers \& Ehlers, 1986). Globules in which shell substances are deposited in a bowl-shaped, meandering pattern may represent an apomorphic characteristic for the Seriata (see Sopott-Ehlers, 1986; Sopott-Ehlers \& Ehlers, 1986).

\section{Adhesive papillae}

In the phylogenetic hypothesis formulated in this paper presence or absence of adhesive papillae (Fig. 1 , characters 13 and 14) which are arranged in an annular zone, function as important defining features for the appropriate taxa (see above). In previous, ultrastructural studies the finding of adhesive papillae in a single member of the Maricola was considered to be representative for the Tricladida as a whole (Tyler, 1976; Rieger \& Tyler, 1979; Ehlers, 1985). Nevertheless, it was already known to Graff (1912-1917: 2729, 2770, 2773 ff.) that Haftpapillen are absent in the Terricola, a conclusion which I am able to confirm from my own experience. Moreover, my studies showed that adhesive papillae are also absent in the Paludicola. However, the distribution of the character states is such that a number of species require further discussion.

In Pentacoelum punctatum and P. fucoideum adhesive papillae are confined to the very hind end of the body, the annular adhesive zone is absent (cf. Sluys \& Bush, 1988). It is here postulated that in these species restriction of adhesive papillae to the tail is a case of reduction of the annular zone of Haftpapillen. That $P$. punctatum and $P$. fucoideum are members of the monophylum Maricola is supported by the fact that the species show the defining features of a less inclusive group of maricolans, viz. the family Bdellouridae.

In a number of other supposedly maricolan species reduction has been restricted to the Haftpapillen and does not involve the annular zone as such. This means that in these species there is a marginal adhesive zone but that the secretion of adhesive glands is not discharged via specialized Haftpapillen but through the epidermal cells, as is the case in the Paludicola and the Terricola. Examples of such species are Procerodes kerguelenensis, $\mathrm{Ne}$ sion arcticum, Dinizia divae, D. sanctaehelenae, Jugatovaria spinosa, Tryssosoma jennyae, Puiteca rigida. Instead of postulating that in these species absence of Haftpapillen is the result of loss within the lineage of the Maricola, which has occurred independently of the loss of adhesive papillae in the Terricola and the Paludicola, there is of course 
another way of explaining the data, and that is that these particular species are postulated to be members of the Paludicola. This would indeed remove several cases of parallelism from the phylogenetic tree (Fig. 1), but at the same time it introduces other cases. For example, the above-mentioned species lack the probursal condition and also the outer longitudinal muscle layer in the subepidermal musculature, and spermatophores have never been observed in these animals. Moreover, some of these species, such as Dinizia divae, and Nesion arcticum, have eyes with well-developed lenses. Lensed eyes do not occur in the Paludicola and Terricola but they are known from quite a few maricolans. Thus, with respect to the above-mentioned planarians which are devoid of adhesive papillae it is postulated that they belong to the Maricola (1) because that hypothesis gives a most parsimonious explanation of the data set, and (2) because some of the species possess a feature which is characteristic for a less inclusive group of marine triclads.

It is interesting to note that also in some proseriates loss of Haftpapillen has occurred, viz. Bothrioplana semperi and Otomesostoma auditivum; the latter even lacks adhesive glands (Hofsten, 1907). According to Hofsten (1907) the last-mentioned species would have no use for adhesive glands and Haftpapillen because it lives in the mud of freshwater bodies, in contrast to its marine relatives which need a strong adhesive system in order to survive in the surf-beaten zone. A similar explanation could easily be adopted to account for the absence of Haftpapillen in $B$. semperi because this species also is confined to fresh waters. Since both Dinizia sanctaehelenae and Tryssosoma jennyae have been described from the fresh waters of St. Helena (Ball, 1977d) the same hypothesis seems to explain satisfactorily the absence of Haftpapillen in these species. Adaptive explanations of this kind are burdened with theoretical and practical problems, which need not concern us here. But it is clear that the adaptive hypothesis fails to account for the absence of adhesive papillae in planarians living in the intertidal zone, such as Procerodes kerguelenensis, and Nesion arcticum.

\section{Rhabdites}

The importance of the lack of lamellated rhabdites as a derived feature of the Proseriata diminishes considerably when it is realized that only very few triclads have been examined with respect to this character. But even the few studies that have been published already witness considerable heterogeneity within the Tricladida. Lamellated rhabdites have been found in the freshwater triclads Procotyla fluviatilis (Dendrocoelidae) and Phagocata paravitta (Planariidae) but appeared to be absent in other members of the Dugesiidae and in the only member of the Terricola that has been studied with respect to this character (for references see Ehlers, 1985: 57). If loss of lamellated rhabdites is thought to represent an apomorphy for the Proseriata then two ways are open to explain the presence of this type of rhabdite in the Planariidae and Dendrocoelidae. It may be hypothesized (1) that either the common ancestor of the Terricola and the Paludicola lost this feature and that it re-appeared again in the Planariidae and Dendrocoelidae or (2) that the Terricola and the Dugesiidae independently lost the lamellated type of rhabdite. Actually, the explanation of the absence or presence of lamellated rhabdites in the Tricladida may even require more than two ad hoc hypotheses, depending upon the character state to be found in the Maricola, which remains to be studied with respect to this feature.

There is also another way of explaining the distribution of the character state 'absence of lamellated rhabdites' within the Seriata. And that is that loss of lamellated rhabdites is thought to be the result of a genetic potential inherited from an ancestor common to both the Proseriata and the Tricladida. The genetic basis for the loss of this particular type of rhabdite is only potentially present in all the descendent taxa but it is not expressed in every member of the resultant taxonomic groups. In this view absence of lamellated rhabdites is not seen as an apomorphy for the Proseriata but is thought to be an underlying synapomorphy (cf. Saether, 1983) asserting the monophyletic status of the Seriata. 


\section{Taxonomic implications}

Some technical consequences of the present phylogenetic hypothesis are the following. In 1925 Steinböck united the aquatic triclads in the new taxon Haploneura and on the basis of the position of the copulatory bursa he coined the new taxon names Retrobursalia and Probursalia for the marine and freshwater planarians, respectively. In view of the phylogenetic hypothesis formulated above and in accordance with opinions of previous workers (Marcus, 1963; Holmquist \& Karling, 1972; Ball, 1974a), the names Retrobursalia and Probursalia have lost much of their initial usefulness. Since some definitely probursal triclads (Probursa) as well as planarians with tendencies towards the probursal condition (e.g. Obrimoposthia ohlini, Cercyra hastata) are here postulated to be members of the monophyletic group of marine triclads, there are no compelling reasons to abandon Hallez' old category names Maricola and Paludicola.

A more important consequence of the present study is that the Haploneura has lost its taxonomic integrity because the category is based on a polyphyletic group. In principle, category names should refer to monophyletic taxa and therefore there is no room for the Haploneura. Steinböck's (1925) name Diploneura still is a valid alternative for Hallez' Terricola.

\section{Epilogue}

I have attempted to formulate an hypothesis of the phylogenetic relationships of the triclads which fits best the data set available at present. For that purpose a phylogenetic tree has been presented which provides the most parsimonious representation of the character state distributions used in this study. However, the principle of parsimony has no bearing on the correctness of the end result, it merely enables us to formulate an hypothesis which is most easily subjected to further testing. It is my hope that the present study provides future workers with ample opportunities for either refutation or corroboration of the proposed phylogenetic tree.

\section{List of species and genera mentioned}

Acromyadenium Beauchamp, 1931

Archimonocelis Meixner, 1938

Asilomaria Karling, 1967

Baikalobia raddei (Zabusov, 1911)

Balliania thetisae Gourbault, 1978

Bdellasimilis barwicki Richardson, 1968

Bdellocephala brunnea Ijima \& Kaburaki, 1916

Bdellocephala schneideri Komarek, 1930

Bdelloura candida (Girard, 1850)

Bdelloura propinqua Wheeler, 1894

Bipalium ephippium Loman, 1890

Bipalium fuscatum (Stimpson, 1857)

Bipalium kewense (Mosely, 1878)

Bipalium multilineatum Makino \& Shirasawa, 1983

Bothrioplana semperi Braun, 1881

Caspioplana pharyngosa Zabusova, 1951

Cercyra hastata Schmidt, 1861

Cercyra teissieri Steimann, 1930

Cura patagonica (Borelli, 1901)

Cura pinguis (Weiss, 1909)

Dendrocoelopsis Kenk, 1930

Dendrocoelum album (Steimann, 1910)

Dendrocoelum infernale (Steimann, 1907)

Dendrocoelum lacteum (Müller, 1774)

Dendrocoelum maculatum Stanković \& Komárek, 1927

Dendrocoelum sanctinaumi (Stanković \& Komárek, 1927)

Dendrocoelum mrazeki (Vejdovsky, 1895)

Dendrocoelum subterraneum (Komarek, 1919)

Dinizia divae Marcus, 1947

Dinizia sanctaehelenae Ball, 1977

Dolichoplana Moseley, 1877

Dugesia andina (Borelli, 1895)

Dugesia annandalei (Kaburaki, 1918)

Dugesia batuensis (Ball, 1970)

Dugesia boehmigi (Weiss, 1909)

Dugesia burmaensis (Kaburaki, 1918)

Dugesia gonocephala (Dugès, 1830)

Dugesia graffi (Weiss, 1909)

Dugesia hoernesi (Weiss, 1909)

Dugesia lugubris (Schmidt, 1861)

Dugesia nannophallus Ball, 1970

Dugesia neumanni (Neppi, 1904)

Dugesis polychroa (Schmidt, 1861)

Dugesia seclusa (Beauchamp, 1940)

Eviella hynesae Ball, 1977

Geoplana nasuta Loman, 1878

Geoplana sieboldi Graff, 1899

Girardia Ball, 1974

Jugatovaria spinosa Sluys \& Ball, 1989

Kenkia Hyman, 1937

Kontikia bulbosa Sluys, 1983

Kontikia orana Froehlich, 1955

Macrocotyla Hyman, 1956

Micaplana misae Kato, 1937 
Microplana Vejdovsky, 1890

Microplana aberana (Mell, 1904)

Microplana henrici (Bendl, 1909)

Microplana monacensis (Heinzel, 1929)

Microplana purpurea (Bendl, 1909)

Microplana richardi (Bendl, 1909)

Microplana scharffi (Graff, 1899)

Microplana terrestris (Müller, 1774)

Mitchellia sarawakana Kawakatsu \& Chapman, 1983

Neppia schubarti (Marcus, 1946)

Nesion arcticum Hyman, 1956

Oahuhawaiiana kazukolinda Kawakatsu \& Mitchell, 1984

Obrimoposthia ohlini (Bergendal, 1899)

Obrimoposthia wandeli (Hallez, 1906)

Opisthobursa Benazzi, 1972

Oregoniplana opisthopora Holmquist \& Karling, 1972

Otomesostoma auditivum (Plessis, 1874)

Pacifides psammophilus Holmquist \& Karling, 1972

Pelmatoplana sondaica (Loman, 1890)

Pentacoelum fucoideum Westblad, 1935

Pentacoelum punctatum (Brandtner, 1935)

Phagocata armeniaca (Komárek, 1916)

Phagocata leptophallus (Reisinger, 1963)

Phagocata ochridana (Stanković \& Komárek, 1927)

Phagocata paravitta (Reisinger, 1923)

Planaria torva (Müller, 1774)

Platydemus victoriae (Dendy, 1891)

Polycelis sabussowi (Seidl, 1911)

Polycladodes Steinmann, 1910

Probursa moei Corrêa, 1960

Probursa veneris Hyman, 1944

Procerodes dohrni Wilhelmi, 1909

Procerodes lobata (Schmidt, 1861)

Procerodes harmsi Lehmensick, 1937

Procerodes kerguelenensis Hyman, 1958

Procerodes trigonocephala Ijima \& Kaburaki, 1916

Procotyla fluviatilis Leidy, 1857

Puiteca rigida Sluys \& Ball, 1989

Rhynchodemus (Microplana) richardi Bendl, 1909

Romankenkius Ball, 1974

Romankenkius kenki Ball, 1974

Rhodax evelinae Marcus, 1946

Sorocelis Grube, 1872

Sorocelis hepatizon (Grube, 1872)

Spathula Nurse, 1950

Spathula camara Ball, 1977

Spathula dittae Ball \& Tran, 1979

Spathula fontinalis Nurse, 1950

Spathula gourbaultae Ball, 1977

Spathula ochyra Ball \& Tran, 1977

Spathula truculenta Ball, 1977

Spathula tryssa Ball, 1977

Sphalloplana Beauchamp, 1931

Syncoelidium pellucidum Wheeler, 1894

Tryssosoma jennyae Ball, 1977

\section{Acknowledgments}

Literature study and specimen examination at the Department of Biology, Memorial University of Newfoundland (JulyAugust 1986) was made possible by grants from the Netherlands Organization for Scientific Research (NWO) (grant R87- 204), the Dutch Ministry of Education and Science, and the Department of external Affairs of the Government of Canada; Prof. Dr. Ian R. Ball and the staff of the Department of Biology at MUN are thanked for putting their facilities at my disposal. I thank Prof. Dr. I.R. Ball, Drs. U. Ehlers, B. Sopott-Ehlers, and E.J. de Vries for valuable comments on the manuscript, though they cannot be held responsible for obscurities or errors that remain.

\section{References}

Ax, P., 1956. Monographie der Otoplanidae (Turbellaria). Akad. Wiss. Lit. Mainz, Abh. Math.-Naturw. Kl., 13: 499-796 ('1955').

Ax, P., 1957. Ein chordoides Stützorgan des Entoderms bei Turbellarien. Z. Morph. Ökol. Tiere, 46: 389-396.

Ax, P., 1961. Verwandtschaftsbeziehungen und Phylogenie der Turbellarien. Ergeb. Biol., 24: 1-68.

Ax, P., 1984. Das phylogenetische System: 1-349 (Gustav Fischer Verlag, Stuttgart, New York).

Ax, P. \& E. Schulz, 1959. Ungeschlechtliche Fortpflanzung durch Paratomie bei acoelen Turbellarien. Biol. ZentrBl., 78: 613-621.

Ball, I.R., 1970. Freshwater triclads (Turbellaria, Tricladida) from the oriental region. Zool. J. Linn. Soc., 49: 271-294.

Ball, I.R., 1974a. A contribution to the phylogeny and biogeography of the freshwater triclads (Platyhelminthes: Turbellaria). In: N.W. Riser \& M.P. Morse (eds.), Biology of the Turbellaria: 339-401 (McGraw-Hill, New York).

Ball, I.R., 1974b. A new genus of freshwater planarian from Australia (Platyhelminthes: Turbellaria). J. Zool., Lond., 174: 149-158.

Ball, 1.R., 1974c. A new genus of freshwater triclad from Tasmania, with reviews of the related genera Cura and Neppia (Turbellaria, Tricladida). Life Sci. Contr. Roy. Ont. Mus., 99: 1-48.

Ball, I.R., 1977a. On the phylogenetic classification of aquatic planarians. Acta Zool. Fenn., 154: 21-35.

Ball, I.R., 1977b. A new and primitive retrobursal planarian from Australian fresh waters (Platyhelminthes, Turbellaria, Tricladida). Bijdr. Dierk., 47: 149-155.

Ball, I.R., 1977c. A monograph of the genus Spathula (Platyhelminthes: Turbellaria: Tricladida). Aust. J. Zool., Suppl. Ser., 47: 1-43.

Ball, I.R., 1977d. Turbellaria. La faune terrestre de l'Ile de Sainte-Hélène VI-2. Ann. Mus. roy. Afr. centr., (Sci. zool.) 220: 492-511.

Ball, I.R., 1981. The phyletic status of the Paludicola. Hydrobiologia, 84: 7-12. 
Ball, I.R. \& T.B. Reynoldson, 1981. British planarians: 1-141 (Cambr. Univ. Press, Cambridge).

Ball, I.R. \& T.V. Tran, 1979. New freshwater triclads from Tasmania (Platyhelminthes, Turbellaria). Bijdr. Dierk., 49: 153-161.

Beauchamp, P. de, 1961. Classe des Turbellariés: 35-212. In: P.P. Grassé (ed.), Traité de Zoologie, 4. (Masson et Cie., Paris).

Benazzi, M. \& V. Gremigni, 1982. Developmental biology of triclad turbellarians: 151-211. In: F.W. Harrison \& R.C. Cowden (eds.), Developmental biology of freshwater invertebrates (Alan R. Liss, New York).

Bendl, W.E., 1909. Beiträge zur Kenntnis des Genus Rhynchodemus. Z. wiss. Zool., 89: 291-320 +2 pls.

Berninger, J., 1911. Über die Einwirkung des Hungers auf Planarien. Zool. Jahrb. (Allg. Zool. Physiol. Tiere), 30: 181-216.

Beveridge, M., 1982. Taxonomy, environment and reproduction in freshwater triclads (Turbellaria: Tricladida). Int. J. Invert. Repr., 5: 107-113.

Bock, S., 1913. Studien über Polycladen. Zool. Bidrag Uppsala, 2: $31-343+8$ pls.

Bresslau, E., 1933. Turbellaria: 52-293. In: Kükenthal \& Krumbach, Handbuch der Zoologie, 2 (1): (W. de Gruyter \& Co., Berlin, Leipzig).

Brooks, D.R., R.T. O'Grady \& D.R. Glen, 1985a. Phylogenetic analysis of the Digenea (Platyhelminthes: Cercomeria) with comments on their adaptive radiation. Can. J. Zool., 63: 411-443.

Brooks, D.R., R.T. O'Grady \& D.R. Glen, 1985b. The phylogeny of the Cercomeria Brooks, 1982 (Platyhelminthes). Proc. Helminth. Soc. Wash., 52: 1-20.

Calow, P. \& D.A. Read, 1986. Ontogenetic patterns and phylogenetic trends in freshwater flatworms (Tricladida); constraint or selection? Hydrobiologia, 132: 263-272.

Carlé, R., 1935. Beiträge zur Embryologie der Landplanarian I. Frühentwicklung, Bau und Funktion des Embryonalpharynx. Z. Morph. Ökol. Tiere, 29: 527-558.

Cernosvitov, L., 1931. Studien über die Samenresorption III. Die Samenresorption bei den Tricladen. Zool. Jahrb. (Anat. Ont. Tiere) 54: $295-332+3$ pls.

Claparède, R.E., 1863. Beobachtungen über Anatomie und Entwicklungsgeschichte wirbelloser Tiere: $120+18$ pls. (Wilhelm Engelmann, Leipzig).

Dahm, A.G., 1960. Dendrocoelopsis spinosipenis (Kenk) from Yugoslavia and Sweden, and Digonoporus macroposthia An der Lan (Turbellaria Tricladida Paludicola). Lund Univ. Ärsskrift, (n. F.) (2) 56: 1-39.

Ehlers, U., 1985. Das phylogenetische System der Plathelminthes: 1-137 (Gustav Fischer, Stuttgart, New York).

Froehlich, C.G., 1955. Sôbre morfologia e taxonomia das Geoplanidae. Bol. Fac. Fil. Ciênc. Letr., Univ. S. Paulo, (Zool.)., 19: $195-251+14$ pls.

Froehlich, C.G., 1967. A contribution to the zoogeography of neotropical land planarians. Acta zool. Lilloana, 23: 153-162.
Gourbault, N., 1972. Recherches sur les triclades paludicoles hypogés. Mém. Mus. natn. Hist. Nat., (A) 73: 1-249 + 3 pls.

Graff, L. von, 1899. Monographie der Turbellarien II, Tricladida Terricola (Landplanarien): 1-574 (W. Engelmann, Leipzig).

Graff, L. von, 1912-1917. Tricladida: 2601-3369 + 64 pls. In: H.G. Bronn's Klassen und Ordnungen des Tier-Reichs, Bd. IV Vermes, Abt. IC: Turbellaria, II Abt.: Tricladida (Winkler, Leipzig).

Gremigni, V., 1979. An ultrastructural approach to planarian taxonomy. Syst. Zool., (28): 345-355.

Gremigni, V., 1981. Ultrastructural characters in planarian taxonomy: a reply to S. Tyler. Syst. Zool., 30: 74-76.

Gremigni, V. \& M. Nigro, 1982. An ultrastructural investigation of oogenesis in marine triclads. Caryologia, 35: 129.

Gremigni, V. \& M. Nigro, 1983. An ultrastructural study of oogenesis in a marine triclad. Tissue \& Cell, 15: 405-415.

Gremigni, V., M. Nigro \& M.S. Settembrini, 1986. Ultrastructural features of oogenesis in some marine neoophoran turbellarians. Hydrobiologia, 132: 145-150.

Heinzel, L., 1929. Zur Kenntnis der Rhynchodemiden. Zool. Jahrb. (Syst.), 56: 425-462 + 2 pls.

Hennig, W., 1966. Phylogenetic systematics: 1-263 (Univ. of Illinois Press, Urbana, Illinois).

Hennig, W., 1984. Aufgaben und Probleme stammesgeschichtlicher Forschung. Pareys Studientexte, 35: 1-65 (Paul Parey, Berlin, Hamburg).

Hesse, R., 1902. Untersuchungen über die Organe der Lichtempfindung bei niederen Tieren VIII. Z. wiss. Zool., 72: $565-656+1 \mathrm{pl}$.

Hofsten, N. von, 1907. Studien über Turbellarien aus dem Berner Oberland. Z. wiss. Zool., 85: 391-654 + 6 pls.

Hofsten, N. von, 1918. Anatomie, Histologie und systematische Stellung von Otoplana intermedia Du Plessis. Zool. Bidrag Uppsala, 7: 1-74 + 2 pls.

Holmquist, C. \& T.G. Karling, 1972. Two new species of interstitial marine triclads from the north American pacific coast, with comments on evolutionary trends and systematics in Tricladida (Turbellaria). Zool. Scr., 1: 157-184.

Hyman, L.H., 1951. The invertebrates, vol. 2, Platyhelminthes and Rhynchocoela: 1-550 (McGraw-Hill, New York).

Kaburaki, T., 1917. Notes on Japanese triclads II. Annot. zool. Japon., 9: 443-449.

Kaburaki, T., 1918. Freshwater triclads from the basin of the Inle Lake. Rec. Indian Mus., 14: 187-194 + 1 pl.

Kaburaki, T., 1922. On some Japanese freshwater triclads, with a note on the parallelism in their distribution in Europe and Japan. J. Coll. Sci. Tokyo Imp. Univ., 44: 1-71 + 1 pl.

Karling, T.G., 1931. Untersuchungen über Kalyptorhynchia (Turbellaria Rhabdocoela) aus dem Brackwasser des Finnischen Meerbusens. Acta zool. Fenn., 11: 1-66.

Karling, T.G., 1940. Zur Morphologie und Systematik der Alloeocoela cumulata und Rhabdocoela lecithophora (Turbellaria). Acta zool. Fenn., 26: 1-260 + 17 pls.

Karling, T.G., 1949. Studien über Kalyptorhynchien (Turbellaria). II. Die Familien Karkinorhynchidae und Diascorhynchi- 
dae. Acta Zool. Fenn., 58: 1-42.

Karling, T.G., 1967. Marine Turbellaria from the Pacific coast of North America. IV. Coelogynoporidae and Monocelididae. Arkiv Zoologi, 18: 493-528.

Karling, T.G., 1974. On the anatomy and affinities of the Turbellarian orders. In: N.W. Riser \& M.P. Morse (eds.), Biology of the Turbellaria: 1-16 (McGraw-Hill, New York).

Karling, T.G. \& V. Mack-Fira, 1973. Zur Morphologie und Systematik der Gattung Paramesostoma Attems (Turbellaria Typhloplanoida). Sarsia, 52: 155-170.

Kawakatsu, M. \& R.W. Mitchell, 1981. Redescription of Kenkia rhynchida, a troglobitic planarian from Oregon, and a reconsideration of the family Kenkiidae and its genera (Turbellaria, Tricladida, Paludicola). Annot. Zool. Japon., 54: 125-141.

Kenk, R., 1925. Zur Anatomie von Dendrocoelum spinosipenis Kenk (Turbellaria, Tricladida). Zool. Anz., 63: 131-146.

Kenk, R., 1930. Beiträge zum System der Probursalier (Tricladida paludicola). Zool. Anz., 89: 145-162.

Kenk, R., 1975. Fresh-water triclads (Turbellaria) of North America. VII. The genus Macrocotyla. Trans. Amer. Microsc. Soc., 94: 324-339.

Kenk, R., 1978. The planarians (Turbellaria: Tricladida: Paludicola) of Lake Ohrid in Macedonia. Smiths. Contr. Zool., 280: $1-56$.

Krsmanovic, K., 1898. Beiträge zur Anatomie der Landplanarien. Z. wiss. Zool., 65: 87-118.

Lang, A., 1881. Der Bau von Gunda segmentata und die Verwandtschaft der Plathelminthen mit Coelenteraten und Hirudineen. Mitth. zool. Stat. Neapel, 3: 187-251 + 3 pls.

Loman, J.C.C., 1890. Über neue Landplanarien von den SundaInseln: 131-158 + 2 pls. In: M. Weber, Zoologische Ergebnisse einer Reise in Niederländisch Ost-Indien (E.J. Brill, Leiden).

Luther, A., 1955. Die Dalyelliiden (Turbellaria Neorhabdocoela). Acta Zool. Fenn., 87: 1-337 + XI.

Luther, A., 1963. Die Turbellarien Ostfennoskandiens, IV. Neorhabdocoela, 2. Fauna Fenn., 16: 1-163.

Maddison, W.P., M.J. Donoghue \& D.R. Maddison, 1984. Outgroup analysis and parsimony. Syst. Zool., 33: 83-103.

Makino, N. \& Y. Shirasawa, 1986. Biology of long slender land planarians (Turbellaria) in Tokyo and environs. Hydrobiologia, 132: 229-232.

Marcus, E., 1946. Sôbre Turbellaria brasileiros. Bol. Fac. Fil. Ciênc. Letr., Univ. S. Paulo, (Zool.) 11: 5-253.

Marcus, E., 1953. Turbellaria Tricladida. Explor. Parc Natn. Upemba, 21: 1-62.

Marcus, E., 1955. Turbellaria. In: B. Hanström, P. Brinck \& G. Rudebeck, South African Animal Life, 1: 101-151 (Results of the Lund University Expedition in 1950-1951, Uppsala).

Marcus, E., 1963. Eine neue Meerestriclade von São Paulo. Zool. Beiträge, 9: 441-446.

Marcus, E., 1970. Turbellaria (Addenda). South African Animal Life, 14: 9-18 (Results of the Lund University Expedition in 1950-1951, Uppsala).

Meixner, J., 1928. Der Genitalapparat der Tricladen und seine Beziehungen zu ihrer allgemeinen Morphologie, Phylogenie,
Ökologie und Verbreitung. Z. Morph. Ökol. Tiere, 11: 570-612.

Meixner, J., 1938. Turbellaria (Strudelwürmer). Tierwelt Nordund Ostsee, 4b: 1-146.

Mell, C., 1904. Die von Oscar Neumann in Nordost-Afrika gesammelten Landplanarien. Zool. Jahrb. (Syst.), 20: $471-490+1 \mathrm{pl}$.

Minelli, A., 1977. A taxonomic review of the terrestrial planarians of Europe. Boll. Zool., 44: 399-419.

Neppi, V., 1904. Über einige exotische Turbellarien. Zool. Jahrb. (Syst.), 21: 303-326.

Okugawa, K., 1939. Probursalia (Tricladida-Paludicola) of Manchoukuo. Annot. Zool. Japon., 18: 155-164 + 1 pl.

Reisinger, E., 1923. Turbellaria. In: P. Schulze, Biologie der Tiere Deutschlands, 6 (4): 1-64.

Reisinger, E., 1925. Untersuchungen am Nervensystem der Bothrioplana semperi Braun (zugleich ein Beitrag zur Technik der vitalen Nervenfärbung und zur vergleichenden Anatomie des Plathelminthennervensystems). Z. Morph. Ökol. Tiere, 5: 119-149.

Reisinger, E., 1940. Die cytologische Grundlage der parthogenetische Dioogonie. Chromosoma, (B) 1: 531-553.

Reisinger, E., 1963. Über einige dinarische 'Endemiten' im Ostalpenraum. Verhandl. Deutsch. zool. Ges. Wien, 1962: $682-688$.

Remane, A., 1951. Die Bursa-Darmverbindung und das Problem des Enddarmes bei Turbellarien. Zool. Anz., 146: 275-291.

Rieger, R.M., 1974. A new group of Turbellaria Typhloplanoida with a proboscis and its relationships to Kalyptorhynchia. In: N.W. Riser \& M.P. Morse, Biology of the Turbellaria: 23-62 (McGraw-Hill, New York).

Rieger, R.M., 1986. Asexual reproduction and the turbellarian archetype. Hydrobiologia, 132: 35-45.

Rieger, R. \& S. Tyler, 1979. The homology theorem in ultrastructural research. Amer. Zool., 19: 655-664.

Saether, O.A., 1983. The canalized evolutionary potential: inconsistencies in phylogenetic reasoning. Syst. Zool., 32: 343-359.

Schockaert, E. \& T.G. Karling, 1970. Three new anatomically remarkable Turbellaria Eukalyptorhynchia from the North American Pacific coast. Ark. Zool., (2) 23: 237-253.

Seidl, H.H., 1911. Beiträge zur Kenntnis centralasiatischer Tricladen. Z. wiss. Zool., 48: 31-68.

Seilern-Aspang, F., 1956. Frühentwicklung einer marine Triclade (Procerodes lobata O. Schmidt). Roux' Arch. Entwickl.-Mech. Org., 148: 589-595.

Skaer, R.J., 1971. Planarians. In: G. Reverberi (ed.), Experimental embryology of marine and freshwater invertebrates: 104-125 (North-Holland Publ. Comp., Amsterdam).

Sluys, R. \& I.R. Ball, 1985. On Bothrioplana semperi from Australia, with a review of the species (Platyhelminthes, Proseriata, Bothrioplanidae). Beagle, 2: 129-137.

Sluys, R. \& I.R. Ball, 1989. A synopsis of the marine triclads of Australia and New Zealand (Platyhelminthes, Tricladida, Maricola). Invertebrate Taxonomy, 2: 915-959. 
Sluys, R. \& L.F. Bush, 1988. On Pentacoelum punctatum (Brandtner, 1935): an amphi-atlantic marine triclad (Platyhelminthes, Tricladida, Maricola). Trans. Amer. Microsc. Soc., 107: $162-170$.

Sluys, R. \& E.J. de Vries, 1988. The aquatic triclads of the Crozet Islands. Zool. J. Linn. Soc., Lond., 94: 203-217.

Sopott-Ehlers, B., 1985. The phylogenetic relationships within the Seriata (Platyhelminthes). In: S. Conway Morris et al. (eds.), The origin and relationships of lower invertebrates. Syst. Ass. Spec. Vol., 28: 159-167 (Clarendon Press, Oxford).

Sopott-Ehlers, B., 1986. Fine-structural characteristics of female and male germ cells in Proseriata Otoplanidae (Platyhelminthes). Hydrobiologia, 132: 137-144.

Sopott-Ehlers, B. \& U. Ehlers, 1986. Differentiation of male and female germ cells in Neoophoran plathelminthes. In: $\mathbf{M}$. Porchet, J.-C. Andries \& A. Dhainaut (eds.), Advances in Invertebrate Reproduction, 4: 187-194.

Steinböck, O., 1924. Untersuchungen über die GeslechtsDarmverbindung bei Turbellarien nebst einem Beitrag zur Morphologie des Trikladendarmes. Z. Morph. Ökol. Tiere, 2: 461-504.

Steinböck, O., 1925. Zur Systematik der Turbellaria metamerata, zugleich ein Beitrag zur Morphologie des TricladenNervensystems. Zool. Anz., 64: 165-192.

Steinböck, O., 1966. Die Hofsteniiden (Turbellaria acoela). Z. zool. Syst. Evol.-Forsch., 4: 58-195.

Tajika, K.-I., 1979. Marine Turbellarien aus Hokkaido, Japan III. Nematoplana Meixner, 1938 (Proseriata, Nematoplanidae). J. Fac. Sci., Hokkaido Univ., (6) (Zool.) 22: 69-87.

Tajika, K.-I., 1981. Eine neue Art der Gattung Archimonocelis (Turbellaria: Proseriata: Monocelididae) aus Hokkaido, Japan. Proc. Jap. Soc. Syst., (Zool.) 21: 1-9.
Tajika, K.-I., 1982a. Morphologisch-phylogenetische Untersuchungen an der Familie Coelogynoporidae (Turbellaria, Proseriata), J. Fac. Sci., Hokkaido Univ., (6) (Zool.) 23: 13-62.

Tajika, K.-I., 1982b. Eine neue Gattung der Familie Nematoplanidae (Turbellaria, Proseriata) aus Hokkaido, Japan. Annot. zool. Japon., 55: 9-25.

Thomas, M.B., 1986. Embryology of the Turbellaria and its phylogenetic significance. Hydrobiologia, 132: 105-115.

Tyler, S., 1976. Comparative ultrastructure of adhesive systems in the Turbellaria. Zoomorphologie, 84: 1-76.

Tyler, S., 1981. Ultrastructural characters in planarian taxonomy: another point of view. Syst. Zool., 30: 71-73.

Vejdovsky, F., 1895. Zur vergleichenden Anatomie der Turbellarien. Z. wiss. Zool., 60: 90-214.

Watrous, L.E. \& Q.D. Wheeler, 1981. The out-group comparison method of character analysis. Syst. Zool., 30: 1-11.

Weiss, A., 1910. Beiträge zur Kenntnis der australischen Turbellarien. Z. wiss. Zool., 94: 541-604 + 4 pls.

Westblad, E., 1935. Pentacoelum fucoideum, ein neuer Typ der Turbellaria metamerata. Zool. Anz., 111: 65-87.

Wiley, E.O., 1981. Phylogenetics - The theory and practice of phylogenetic systematics: 1-439 (Wiley \& Sons, New York).

Wilhelmi, J., 1909. Tricladen. Fauna Flora Golf. Neapel, 32: $1-405+16$ pls. (Friedländer, Berlin).

Winsor, L., 1986. Land planarians (Turbellaria: Tricladida: Terricola) introduced into Australia - 2. Kontikia orana Froehlich, 1955. Victorian Natural., 103: 9-11.

Zabusova, Z., 1951. A new species of Planaria from the Caspian Sea. Proc. Murgab Hydrobiol. Stat. Acad. Sci. USSR, 1951: 115-126 (in Russian).

Received: 27 October 1988 